\title{
INTERSECCIONES ENTRE EVALUACIÓN \\ PARTICIPATIVA Y PEDAGOGÍA SOCIAL
}

\author{
INTERSECTIONS BETWEEN \\ PARTICIPATORY EVALUATION AND SOCIAL PEDAGOGY
}

\section{INTERSECÇÕES ENTRE AVALIAÇÃO PARTICIPATIVA E PEDAGOGIA SOCIAL}

\author{
Jill Anne Chouinard, Peter Milley y J. Bradley Cousins
}

UnIVERSitY OF OtTAWA

\begin{abstract}
RESUMEN: Debido a su desarrollo y evolución, hoy día se discute la existencia de vínculos entre la evaluación participativa y la pedagogía social. En este artículo analizamos las afinidades entre estos dos campos científicos, para identificar puntos de enlace y divergencia, con mayor profundidad que lo desarrollado hasta el presente. Siguiendo una revisión reciente de más 100 estudios empíricos de evaluación participativa (Cousins \& Chouinard, 2012), reexaminamos una selección de temas emergentes desde una perspectiva pedagógico-social. Destacamos similitudes y diferencias, y exponemos una serie de problemas a tener en cuenta en la evaluación participativa, con el fin de abrir el diálogo entre aquellos profesionales involucrados en la investigación y la práctica de uno u otro campo.
\end{abstract}

PALABRAS CLAVE: pedagogía social; evaluación participativa; cambio social.

ABSTRACT: It can be argued that participatory evaluation and social pedagogy share several interconnections given their respective developments and evolutions. In this paper we explore affinities between these two domains of inquiry in order to understand points of intersection and departure at deeper levels that has occurred to date. Following a recent review and integration of more than 100 empirical studies of participatory evaluation (Cousins \& Chouinard, 2012) we re-examine a selection of emergent themes through a social-pedagogical lens. We highlight similarities and differences and then lay out a set of issues for considerations for participatory evaluation and in the interest of opening an dialogue among those engaged in research and practice within either sphere if interest. 
KEYWORDS: social pedagogy; participatory evaluation; social change.

RESUMO: Se pode argumentar que a avaliação participativa e a pedagogia social compartem numerosas interseções, dada aos seus respectivos desenvolvimentos e evoluções. No presente artigo procura-se explorar as afinidades entre estes domínios de investigação, com a finalidade de entender os pontos de interseção e saída à níveis mais profundos do que se tem feito até o momento. Seguindo uma recente revisão e integração de mais de 100 estudos empíricos de avaliação participativa (Cousins \& Chouinard, 2012), se reexamina uma seleção de temas emergentes através de lentes sócio-pedagógicas. Se põe em evidência similitudes e diferenças e posteriormente se sugere uma série de considerações para a avaliação participativa, com o interesse de abrir um diálogo entre aquelas pessoas envolvidas na investigação e na prática.

PALAVRAS-CHAVE: pedagogia social; avaliação participativa; mudança social. 


\section{Introducción}

La evaluación participativa es un enfoque de investigación social con una larga historia, particularmente en el ámbito de la cooperación para el desarrollo internacional, pero también en la evaluación de programas sociales, educativos y de servicios humanos, mayormente en el contexto angloamericano y occidental. Como autores, escribimos desde nuestra experiencia en evaluación participativa en América del Norte y en contextos de desarrollo internacional, en base a nuestra comprensión de los conocimientos, basados en la investigación acerca de este enfoque. Consideramos que la evaluación participativa pertenece a un tipo de investigación denominado 'enfoques de colaboración en evaluación', que incluye aspectos, como: la investigación-acción participativa, evaluación democrática, evaluación iluminativa y evaluación para el empoderamiento, entre otros muchos. Dentro de lo que es crucial en el ámbito de la evaluación participativa, está la asociación de profesionales con formación en evaluación e investigación sistemática y miembros de la comunidad implicados en los programas, los cuales no han recibido formación específica. Todos ellos trabajan conjuntamente para co-producir conocimientos evaluativos acerca del respectivo programa social, educativo, comunitario o de servicios humanos, en cuestión (Cousins \& Chouinard, 2012).

Por lo general, se dice que cualquier enfoque de evaluación tiene dos funciones primarias ${ }^{\top}$. Por una parte, el conocimiento evaluativo puede servir para ayudar a los patrocinadores, diseñadores, directores e implementadores de programas a satisfacer las demandas de rendición de cuentas. Las evidencias evaluativas contribuyen a apoyar y facilitar la toma de decisiones acerca de recursos, diseño y sustentabilidad de los programas; la evaluación puede favorecer la toma de decisiones a la hora de concluir o de ampliar programas a niveles más altos (por ejemplo, de local a nacional). Por otro lado, la evaluación sirve para potenciar el aprendizaje y lo hace de dos maneras diferentes. En primer lugar, los hallazgos de un estudio de evaluación pueden ayudar a considerar detalladamente el diseño, fortalezas y debilidades, efectos positivos o negativos, intencionados o no, del programa. También permiten aclarar o profundizar en la comprensión de los con-

\section{Introduction}

Participatory evaluation is an approach to social inquiry with a long history, particularly in the context of international development but also in the evaluation of social, educational and human service programs in predominantly Anglo-American, Western contexts. As authors, we are writing from within our experiences with participatory evaluation in North American and international development contexts and on the basis of our understanding of research based knowledge about the approach. We view participatory evaluation as belonging to a class of inquiry known as collaborative approaches to evaluation which includes such members as participatory action research, democratic evaluation, illuminative evaluation, and empowerment evaluation, among many others. At the crux of participatory evaluation is the idea of partnership between persons trained in evaluation and systematic inquiry, and members of the program stakeholder community who are not specifically trained. People work in partnership to co-create evaluative knowledge about the respective social, educational, community or human service program in question (Cousins \& Chouinard, 2012).

It is generally argued that any approach to evaluation has two primary functions. ${ }^{2}$ On the one hand, evaluative knowledge can serve to help program sponsors, developers, managers and implementers meet accountability demands. Evaluative evidence can support and inform decisions about program resources, design, and sustainability: evaluation can contribute to decisions to terminate programs or to scale them up to enhance reach to broader levels (e.g., from local to national). On the other hand, evaluation serves to augment learning and it does this in at least two ways. First, findings from an evaluation study can inform thinking about program design, strengths and weaknesses and effects, whether positive or negative, intended or not. It may also clarify or deepen understanding about the contexts in which programs operate. A second way evaluation fosters learning arises from program stakeholder proximity to evaluation. That is, non-evaluator stakeholders can develop evaluation habits of mind (Katz, Sutherland, \& Earl, 2002) or learn to think in systematic ways, as do 
textos en los que se implementan los programas. La segunda vía, a través de la cual la evaluación fomenta el aprendizaje, surge de la proximidad del stakeholder del programa a la evaluación. Es decir, los participantes no-evaluadores pueden desarrollar hábitos mentales de evaluación (Katz, Sutherland \& Earl, 2002) o aprender a pensar de forma sistemática, tal como lo hacen los propios evaluadores. Este tipo de aprendizaje es conocido como 'process use' (Cousins, 2007; Patton, 1998, 2008), y puede ser bastante independiente de cualquier aprendizaje o toma de decisiones resultado de hallazgos evaluativos.

Si bien algunos autores (Fetterman \& Wandersman, 2005) sostienen que los enfoques colaborativos se amoldan a evaluaciones inspiradas en demandas de rendición de cuentas, nosotros nos encontramos un tanto incómodos con este punto de vista. Obviamente, la asociación entre evaluadores y stakeholders es consciente del papel que los evaluadores deben desempeñar, relacionado con el control de la calidad y la adherencia a los estándares de la práctica. No obstante, la posibilidad de que ocurra un sesgo entre los miembros comunitarios del programa puede ser demasiado alta frente a cuestiones complicadas y disyuntivas, como ¿financiar o no financiar?. Durante bastante tiempo, hemos defendido (Cousins \& Earl, 1992; Cousins \& Whitmore, 1998) y seguimos defendiendo (Cousins \& Chouinard, 2012) la idea de que la evaluación participativa es más apropiada para demandas evaluativas orientadas a la formación y la mejora. A este respecto, la importancia de la función del aprendizaje de la evaluación participativa es, sin lugar a dudas, elevada. Chouinard (2013: 244) nos recuerda que "la evaluación en sí misma se considera como un compromiso pedagógico (Schwandt, 2003), ya que el aprendizaje está implicado en la creación y el uso de hallazgos de la evaluación, a través de la involucración de los stakeholders en el proceso y práctica de la evaluación". Según Oakley (1991), "la evaluación participativa es un proceso educativo fundamental, considerado por algunos como un sistema de aprendizaje (Cousins \& Earl, 1992), en el que los inversores trabajan conjuntamente con los evaluadores a la hora de identificar problemas, llevar a cabo tareas de investigación y responder a los hallazgos y resultados de la investigación" (p. 245). evaluators themselves. This type of learning is caIled 'process use,' (Cousins, 2007; Patton, 1998; 2008) and may be quite independent of any learning or decision making that evaluation findings might bring about.

While some (e.g., Fetterman \& Wandersman, 2005) argue that collaborative approaches are suited to evaluations that are inspired by accountability demands, we are somewhat uncomfortable with this perspective. Clearly, there is a role in the partnership for evaluators to play in quality assurance and adherence to professional standards of practice, yet the potential for selfserving bias among program community members may be too great in the face of hardnosed, 'forkin-the-road' evaluation questions (i.e., to fund or not to fund?). We have argued for quite some time (Cousins \& Earl, 1992; Cousins \& Whitmore, 1998) and we continue to argue (Cousins \& Chouinard, 2012) that participatory evaluation is best suited to formative, improvement-oriented evaluation demands. In that respect, the importance of the learning function of participatory evaluation is undeniably elevated. Chouinard (2013, p. 244) reminds us that "evaluation is itself considered a pedagogical undertaking (Schwandt, 2003), as learning is implicated in the creation and use of evaluation findings and through stakeholder involvement in the process and practice of evaluation". And "Participatory evaluation is a fundamentally educational process (Oakley, 1991), considered by some as a learning system (Cousins \& Earl, 1992), where stakeholders work alongside evaluators in identifying issues, carrying out research tasks, and responding to research findings and results." (p. 245).

Oakley (1991) frames the approach in the context of rural development, which is consistent with its roots in international development. In such contexts, participatory evaluation is usually conceptualized as a transformative, empowering process that contributes to capacity building and fosters self-determination among persons, groups and communities in local development contexts. In this way it is normative in form and function; it is as much about learning from the process of inquiry as it is about the findings and evidence such inquiry produces (Brisolara, 1998). More recently, in 
Oakley (1991) encuadra el enfoque en el contexto del desarrollo rural, lo cual es coherente con sus raíces en la cooperación para el desarrollo internacional. En tales contextos, la evaluación participativa está normalmente conceptualizada como un proceso de transformación y empoderamiento que contribuye a crear capacidades y fomenta la autodeterminación entre personas, grupos y comunidades en contextos de desarrollo local. De esta manera, la evaluación participativa es normativa en forma y función; consiste tanto en el aprendizaje, a partir del proceso de investigación, como en los hallazgos y pruebas resultantes de tal investigación (Brisolara, 1998). Más recientemente, en países occidentales desarrollados y mayormente en América del Norte, la evaluación participativa ha adoptado una orientación más práctica, de resolución de problemas, orientada al aprovechamiento de programas y al cambio organizativo, a través de la generación de evidencias. Los hallazgos de investigación conducen a una comprensión más profunda de los puntos fuertes y débiles, efectos y oportunidades, con el fin de mejorar el programa.

En 1998, Cousins y Whitmore acuñaron estas dos vertientes como evaluación participativa transformadora (EP-T; en inglés T-PE) y evaluación participativa práctica (EP-P, en inglés P-PE), diferenciándolas en términos de objetivos y procesos. Ambas contribuyen al desarrollo de una comprensión más profunda a través de la investigación, aunque EP-T está impulsada por intereses políticos (por ejemplo, justicia social, empoderamiento, mejora de la desigualdad social), y EP-P tiene como distintivo la mejora del uso del conocimiento y las pruebas evaluativas. Las dos vertientes pueden diferir en cuanto a la gama de stakeholders comprometidos con la cocreación de conocimiento evaluativo, pero se asemejan al involucrar a los miembros comunitarios del programa en las tareas de la investigación y en la toma de decisiones sobre la misma.

Ya estén orientados a la práctica o a la transformación, es evidente que los procesos participativos favorecen la función de aprendizaje de la evaluación. Nuestro interés en este estudio consiste en analizar este tema en mayor profundidad de lo que se ha hecho hasta el momento. Tratamos de hacerlo examinando la evaluación participativa desde una perspectiva conceptual, la cual, en base a lo que no-
Western, developed countries mainly in North America, participatory evaluation has embraced more of a practical, problem-solving orientation, one that is designed to leverage program and organizational change through the generation of evidence. Findings from inquiry lead to deeper understanding of program strengths and weakness, effects, and opportunities for improvement. In 1998 Cousins and Whitmore coined these two streams as transformative participatory evaluation ( $T$ $\mathrm{PE})$ and practical participatory evaluation (P-PE) and differentiated them in terms of goals and processes. Both subscribe to the development of deeper understanding through inquiry but, whereas T-PE is motivated by political interests (e.g., social justice, empowerment, amelioration of social inequity), enhancing the use of evaluative knowledge and evidence is the hallmark of P.PE. The two streams may also differ in terms of the range of stakeholders involved in the co-creation of evaluative knowledge, but they are similar in terms of engaging program community members in the research tasks and in decision making about the inquiry.

Whether practical or transformative in orientation, it is clear that participatory processes privilege the learning function of evaluation. Our interest in this paper is exploring this theme at deeper levels than has been the case to date. We seek to do so by examining participatory evaluation through a conceptual lens that has not, to our knowledge, been brought to bear on the problem at hand. That lens is social pedagogy, a distinctively European sociological and educational intellectual tradition. Social pedagogy loosely conceived, concerns teaching and learning that occurs in a non-traditional, non-formal educational context, and as such, is a natural choice to frame our inquiry into the learning function of participatory evaluation for at least three important reasons. First, the tradition, which has been variously labelled as "community education" or "educational for sociality" or "social education" (Smith, 2012), describes a range of work straddling interests in education and social work and resonates well with an image of participatory evaluation as interactive, social, and dialogic learning, that might be thought of as "learning-in-practice" or "situated learning" 
sotros conocemos, aún no ha sido aplicada al problema en cuestión. Dicha perspectiva conceptual es la pedagogía social, una tradición intelectual y educativa, distintivamente europea. La pedagogía social, vagamente concebida, se ocupa de la enseñanza y los aprendizajes que ocurren fuera del sistema educativo formal, como tal, es natural que decidamos enmarcar nuestra investigación en la función de aprendizaje de la evaluación participativa, como mínimo, por tres razones importantes. En primer lugar, la tradición, que ha sido diversamente etiquetada como 'educación comunitaria', 'socialidad educativa ' o 'educación social' (Smith, 2012), describe una gama de intereses laborales a horcajadas entre educación y trabajo social, y prospera con una imagen de la evaluación participativa, como aprendizaje interactivo, social y dialógico, que podría ser considerado como 'aprendizaje en la práctica' o 'aprendizaje situado' (Lave \& Wenger, 1991; 527). En segundo lugar, la pedagogía social se interesa distintivamente por el fomento de mejores condiciones y oportunidades sociales para la gente y grupos marginados y sin privilegios; por ello, se complementa satisfactoriamente con la orientación de EP-T a la justicia social y presenta oportunidades interesantes para explotar tales conexiones. En tercer lugar, las aplicaciones de la pedagogía social y la evaluación participativa son de gama amplia y multisectoriales. Se ejercen en contextos en desarrollo y desarrollados, en una amplia gama de intereses prácticos, incluyendo: el desarrollo educativo, sanitario, social y económico de la comunidad. Así pues, nuestro objetivo principal se centra en la siguiente cuestión: ¿̇hasta qué punto y de qué manera pueden la teoría y la práctica de la evaluación participativa beneficiarse de un análisis comparativo con la pedagogía social?.

Abordamos este problema recurriendo a nuestra propia investigación y punto de vista. Concretamente, hemos completado recientemente un extenso análisis de más de 100 estudios sobre evaluación participativa (Cousins \& Chouinard, 2012). De este examen minucioso sobre investigación empírica, se extrajo una serie de temas transversales para su discusión. Más tarde, examinamos más detenidamente la investigación sobre evaluación participativa realizada en contextos desarrollados, lo cual nos llevó definitivamente a incluirla en la base
(Lave \& Wenger, 1991, p. 527). Second, social pedagogy is distinctively interested in promoting better social conditions and outcomes for underprivileged and marginalized people and groups; it thus aligns well with the social justice orientation of T-PE and presents interesting opportunities to exploit such connections. Third, applications of social pedagogy and participatory evaluation are wide-ranging and multi-sectorial. They apply to developing and developed contexts and to a broad range of practical interests including education, health, social, economic and community development. Our principal focus then is "to what extent and how can participatory evaluation theory and practice benefit from a comparative analysis with social pedagogy?'

We approach our response to this problem by drawing on some of our own research and thinking. Specifically we recently completed an extensive analysis and integration of over 100 studies of participatory evaluation (Cousins \& Chouinard, 2012). Emerging from that close examination of empirical research was a set of crosscutting themes for deliberation and discussion. Subsequently, we looked more closely at research on participatory evaluation in development contexts which ultimately led us to add to the data base with an additional body of studies and to revisit the meaning and interpretation of themes in development settings (Chouinard \& Cousins, 2013; in press). We will use these thematic analyses arising from original empirical research on participatory evaluation as a basis for framing our exploration of the intersections between the approach and social pedagogy.

We conduct this work from our location as participatory evaluation specialists, situated in a North American context, with a view to launching an exploratory dialogue with the community of scholars and practitioners of social pedagogy. We thus embark in the spirit of building mutual understanding across different fields and cultures. We do so working from the hypothesis that we share some important philosophical, theoretical and practical common ground. In particular, we believe there may be important affinities that might support more socially pedagogic forms of participatory evaluation. 
de datos, con un conjunto adicional de estudios, y a reconsiderar el significado y la interpretación de temas en ajustes de desarrollo (Chouinard \& Cousins, 2013; en prensa). Emplearemos estos análisis temáticos, resultantes de la investigación empírica original sobre evaluación participativa, como base para estudiar la intersección entre la Evaluación Participativa y la Pedagogía Social.

Realizamos este trabajo desde nuestra situación como especialistas en evaluación participativa, situados en un contexto norteamericano, con el fin de abrir un diálogo exploratorio con la comunidad de académicos y profesionales de pedagogía social. Nos embarcamos así en el esfuerzo por conseguir una comprensión mutua entre diferentes campos y culturas. Y lo hacemos trabajando desde la hipótesis de que compartimos importantes fundamentos filosóficos, teóricos y prácticos. Particularmente, estimamos que pueden haber importantes afinidades que podrían apoyar modelos de evaluación participativa más pedagógico-sociales.

Comenzamos con una recapitulación de nuestra comprensión acerca de conceptos y principios de la pedagogía social, y a partir de este marco conceptual, estudiamos las interconexiones y enlaces entre estos dos campos de investigación. El artículo concluye con algunas lecciones principales aprendidas e inferencias para la práctica de la evaluación participativa.

\section{1. ¿Qué es la Pedagogía Social?}

Similar a otros campos de investigación y práctica académica, la pedagogía social tiene un número de variantes y está constantemente evolucionando, a través de innovaciones y debates filosóficos y metodológicos. La descripción de pedagogía social que presentamos, como interlocutores provenientes de una disciplina diferente, está basada en lecturas de la literatura en lengua inglesa sobre la materia. Admitimos que esto pone límites a nuestra capacidad para crear un retrato verdaderamente representativo de la pedagogía social, la cual tiene una colección de tradiciones históricas y expresiones geográficas, culturales, educativas y políticas (Schugurensky \& Silver, 2013). Damos fe de la existencia de perspectivas divergentes en pedagogía social, incluyendo aquellas que quizás no hemos podido captar, debi-
We begin with a summation of our understanding of social pedagogical concepts and principles and then using this conceptual framework as a lens, explore the interconnections and intersections of these two domains of inquiry. The paper concludes with some principal lessons learned and implications for participatory evaluation practice.

\section{What is Social Pedagogy?}

Similar to other fields of scholarly inquiry and practice, social pedagogy has a number of variants and is continually evolving through ongoing philosophical and methodological debates and innovations. The description of social pedagogy we present here as interlocutors from a different discipline is based on a reading of English language literature on the subject. We recognize this places limits on our capacity to create a truly representative portrayal of social pedagogy, which has an array of historical traditions and geographical, cultural, educational and political expressions (Schugurensky \& Silver, 2013). We acknowledge the existence of divergent perspectives of social pedagogy, including those we may not have been able to capture because of our own disciplinary, cultural, and linguistic limitations. 
do a nuestras propias limitaciones disciplinarias, culturales y lingüísticas.

En sus expresiones contemporáneas, la pedagogía social representa la búsqueda académica y práctica de formas holísticas de educación y cuidado social, que tienen en cuenta explícitamente contextos comunitarios, sociales y políticos. Aquellas personas que trabajan desde la perspectiva de la pedagogía social tratan de promover, a través de medios pedagógicos, el completo desarrollo y crecimiento de individuos como parte de la sociedad (Eriksson \& Markström, 2003). Esto implica asistir, a través de medios pedagógicos, a procesos de integración social, económica y política, $y$, particularmente, abordar los efectos que tiene la marginación - exclusión sobre las personas en estos procesos (Hämäläinen, 2012; Schugurensky \& Silver, 2013).

La pedagogía social (Sozialpädagogik) tiene sus raíces en regiones germánicas y románicas de Europa (Hämäläinen, 2003), donde, en 1844, el pedagogo Karl Mager acuñó el término por primera vez (Lorenz, 1994; 2008; Schugurensky \& Silver, 2013). Basándose en los conocimientos y las prácticas de Rousseau, Pestalozzi y Froebel, los pedagogos sociales propusieron educar al niño o adulto integralmente (por ejemplo, aprender con la cabeza, con el corazón y con las manos) (Smith \& Whyte, 2008), haciendo al mismo tiempo hincapié en los aspectos sociales más amplios de los procesos educativos (Lorenz, 2008). Particularmente, la pedagogía social representaba una búsqueda de "soluciones educativas a problemas sociales, tales como la pobreza y otras formas de desamparo social" (Hämäläinen, 2003: 71). También procuraba ayudar a cumplir las "promesas emancipatorias" y a abordar las "amenazas de fragmentación cultural y desintegración social", relacionadas con la modernización e industrialización de Europa, particularmente en Alemania (Lorenz, 2008: 633).

Con estos objetivos en mente, los partidarios de la pedagogía social han trabajado para que tuviera una presencia significativa en muchas partes de la Europa continental, donde ha adoptado diferentes características en cada país o región (Hämäläinen, 2003; 2012; Schugurensky \& Silver, 2013). Las ideas sociales y educativas progresistas, asociadas en la práctica con la pedagogía social, también se han expandido a otros continentes, mientras que los de-
In its contemporary expressions, social pedagogy represents the scholarly and practical pursuit of holistic forms of education and social care that explicitly take into account community, social and political contexts. Those working from the perspective of social pedagogy seek to promote, through pedagogical means, the full development and growth of individuals as part of society (Eriksson \& Markström, 2003). This involves attending through educational means to processes of social, economic and political integration, and, in particular, addressing the effects on individuals of their marginalization or exclusion in these processes (Hämäläinen, 2012; Schugurensky \& Silver, 2013).

Social pedagogy (Sozialpädagogik) has its roots in Germanic and Romanic regions of Europe (Hämäläinen, 2003), where, in 1844, the educationalist Karl Mager is thought to have first coined the term (Lorenz, 1994; 2008; Schugurensky \& Silver, 2013). Building on the pedagogical insights and practices of Rousseau, Pestalozzi and Froebel, social pedagogues aimed to educate the whole child or person (e.g., learning with heads, hearts, and hands) (Smith \& Whyte, 2008) while emphasizing the broader societal aspects of educational processes (Lorenz, 2008). In particular, social pedagogy represented a search for "educational solutions to social problems, such as poverty and other forms of social distress" (Hämäläinen, 2003, p. 71). It also sought to help fulfill the "emancipatory promises" and to address the "threats of cultural fragmentation and social disintegration" associated with the modernization and industrialization of Europe, in particular Germany (Lorenz, 2008, p. 633).

With these aims in mind, supporters of social pedagogy have worked to establish it as a significant presence in many parts of continental Europe, where it has taken on different characteristics in each country or region (Hämäläinen, 2003; 2012; Schugurensky \& Silver, 2013). The socially and educationally progressive ideas and practices associated with social pedagogy have also spread to other continents, while parallel developments in those jurisdictions have also infused social pedagogy (Koengeter \& Schroeer, 2013). Particular educational, cultural and political expressions of social pedagogy thus exist throughout the world, including manifestations that represent the principles and practices of social pe- 
sarrollos paralelos en sus jurisdicciones han influido también en la pedagogía social (Koengeter \& Schroeer, 2013). Expresiones educativas, culturales y políticas particulares de la pedagogía social existen pues a lo largo de todo el mundo, incluyendo manifestaciones que representan los principios y prácticas de la pedagogía social pero que no necesariamente llevan su etiqueta (Schugurensky \& Silver, 2013). En Sudamérica, por ejemplo, la pedagogía social se ha asociado a formas emancipatorias de la práctica educativa de Paulo Freire (Schugurensky, 2011). En América del Norte, esto se ha interpretado en los conocimientos y prácticas de principios del siglo XX, de figuras como Edward Lindeman, John Dewey, Myles Horton, y Moses Coady (Schugurensky \& Silver, 2013). Desde nuestra perspectiva norteamericana, creemos que existe una fuerte conexión entre la rama emancipatoria y transformadora de la pedagogía social y la pedagogía crítica de finales del siglo XX y principios del siglo XXI, expresada, por ejemplo, en los trabajos de Henry Giroux, Peter McLaren, and Roger Simon, entre otros.

La pedagogía social supone ahora un campo interdisciplinario de estudio académico y una gama de prácticas que abarca una variedad de actividades, ocupaciones y profesiones de cuidado social, que tienen la educación (entendida de forma holística y amplia) como núcleo (Schugurensky \& Silver, 2013; Smith, 2012). La pedagogía social ha ejercido una influencia particularmente en el campo del trabajo social en la Europa continental. En Alemania, Dinamarca, Holanda y Hungría, por ejemplo, se ha aplicado a las actividades de técnicos de juventud, de trabajadores en centros residenciales o de atención diurna, de personas que aconsejan y educan delincuentes, e incluso de terapeutas ocupacionales (Coussée et al., 2010; Galuske, 2009, citado en Smith, 2012). En Francia, el trabajo de educateurs o animateurs socio-culturels está basado en una perspectiva comunitaria, que evoca una línea pedagógico-social (Smith \& Whyte, 2008).

En comparación con Europa, en las jurisdicciones angloamericanas la pedagogía social parece tener una presencia tenue. En el Reino Unido, por ejemplo, ha llegado a formar parte de un diálogo permanente sobre la mejora del cuidado social, a través de enfoques más integrados y holísticos (Coussée et al., 2010; Lorenz, 2008; Smith \& Whyte, 2008), dagogy but do not necessarily sail under its flag (Schugurensky \& Silver, 2013). In South America, for example, social pedagogy has been associated with Paulo Freire's emancipatory forms of educational practice (Schugurensky, 2011). In North America, it has been read into the early $20^{\text {th }}$ century scholarship and practice of figures such as Edward Lindeman, John Dewey, Myles Horton, and Moses Coady (Schugurensky \& Silver, 2013). While, from our North American position, we speculate that there is a close connection between the emancipatory and transformative strand of social pedagogy and the critical pedagogy of the late $2 \mathrm{O}^{\text {th }}$ and early $21^{\text {st }}$ centuries expressed, for example, in the work of Henry Giroux, Peter McLaren, and Roger Simon, among others.

Social pedagogy now signifies an interdisciplinary field of academic study and range of practices that straddle a variety of social care activities, occupations and professions that have education (holistically and broadly understood) at their core (Schugurensky \& Silver, 2013; Smith, 2012). Social pedagogy has particularly had an influence in the domain of social work in continental Europe. In Germany, Denmark, The Netherlands and Hungary, for example, it has been applied to the pursuits of youth, residential or day care workers, those who counsel and educate offenders, and even occupational therapists (Coussée et al., 2010; Galuske, 2009, as cited in Smith, 2012). In another example, the work of eduateurs or animateurs socio-culturels in France is seen to be grounded in a community perspective redolent with a socially pedagogic perspective (Smith \& Whyte, 2008, p. 20).

In comparison to Europe, social pedagogy appears to have a somewhat tenuous presence in Anglo-American jurisdictions. In the United Kingdom, for example, it has recently become part of an ongoing dialogue about improving social care through more integrated, holistic approaches (Coussée et al., 2010; Lorenz, 2008; Smith \& Whyte, 2008) in particular with respect to residential care for children (Cameron et al., 2011); while, in North America, a master's degree program in social and cultural pedagogy was recently established at Arizona State University (Arizona State University, School of Social Transformation). While acknowledging this lack of formal uptake of social pedagogy in Anglo-American jurisdictions, many activities similar to those associated 
particularmente, con el cuidado residencial para niños (Cameron et al., 2011); mientras que en América del Norte, en la Universidad Estatal de Arizona se ha establecido recientemente un programa de máster en pedagogía social y cultural (Arizona State University, School of Social Transformation). Si bien damos fe de la pobre aceptación formal de la pedagogía social en jurisdicciones angloamericanas, muchas actividades similares a las relacionadas con la pedagogía social se pueden observar en países donde las necesidades y los problemas sociales han sido o están siendo abordados a través de medios socialmente progresivos y educativos (Hämäläinen, 2003; Schugurensky \& Silver, 2013). Algunos autores (Coussée et al., 2010; Schugurensky \& Silver, 2013; Smith, 2012) afirman que los principios inherentes en pedagogía social, como ya mencionamos anteriormente, están reflejados en las filosofías educativas de Eduard Lindeman, John Dewey, Myles Horton, Moses Coady y Paulo Freire, las cuales podrían estar más relacionadas con educadores de mentalidad social en un contexto norteamericano. Para una mejor interpretación, desde un punto de vista norteamericano de cómo la pedagogía social puede estar reflejada tácitamente o conectada a estas actividades, es necesario tener una comprensión más completa de qué es la pedagogía social, incluyendo sus objetivos, características definitorias, epistemológicas y metodológicas.

La búsqueda de la claridad conceptual sobre la pedagogía social puede ser bastante elusiva. Ucar (2013) constató que la pedagogía social contemporánea es tan compleja como los contextos sociales a los que se acopla, "dificultando la obtención de una imagen estática para definir, ensamblar o caracterizar la pedagogía social de forma completa y satisfactoria, ya que es móvil y está en constante evolución, al igual que las personas, los grupos y las comunidades" (p. 11). Tras observar que la pedagogía social contemporánea es en teoría incoherente, en vista de sus tradiciones y prácticas, Hämäläinen (2012) ha desarrollado un fructuoso esquema para entenderla mejor. Según su análisis, el término 'pedagogía ' se refiere a "una rama del pensamiento que trata la naturaleza del desarrollo humano y la educación en teoría y práctica" (p. 4); mientras que el término 'social ' tiene tres posibles significados, en base al desarrollo histórico de la pedagogía social. with social pedagogy can be discerned in countries where social needs and problems have been, or are being, addressed through socially progressive educational means (Hämäläinen, 2003; Schugurensky \& Silver, 2013). Some authors (e.g., Coussée et al., 2010; Schugurensky \& Silver, 2013; Smith, 2012) observe the principles inherent in social pedagogy are, as mentioned earlier, reflected in the educational philosophies of Eduard Lindeman, John Dewey, Myles Horton, Moses Coady and Paulo Freire, which may be more familiar to socially-minded educators in a North American context. To better grasp from a North American point of view how social pedagogy might be tacitly reflected in, or connected to, these activities, it is necessary to have a more complete understanding of what social pedagogy is, including its aims, defining characteristics, epistemologies and methodologies.

A search for conceptual clarity about social pedagogy can be quite elusive. Ucar (2013) recently noted that contemporary social pedagogy is as complex as the social contexts in which it is embedded, making it "difficult to obtain a static picture to define, bind or characterize social pedagogy in a complete and satisfactory way [as] it is mobile and is continually evolving, just like people, groups and communities" (p. 11). Observing that contemporary social pedagogy is theoretically incoherent in light of its diverse traditions and practices, Hämäläinen (2012) developed a fruitful schema for better understanding it. Following his analysis, the term 'pedagogy' can be understood as referring to "a branch of thought concerning the nature of human growth and education in theory and practice" (p. 4); while, the term 'social' has three potential meanings based on the historical development of social pedagogy. As part of a social scientific basis for the social professions, social pedagogy variously focuses on:

- improving societal conditions related to education and human development to promote active citizenship, democracy, inclusion and participation and to prevent social disintegration, exclusion, oppression;

- advancing community-based forms of education and human development to promote social skills, communicative culture and to prevent isolation, loneliness, and poor relationships between people; and 
Como parte de una base científica, para las profesiones sociales, la pedagogía social se centra diversamente en:

- Mejorar las condiciones de la sociedad relacionadas con la educación y el desarrollo humano para promover la ciudadanía activa, la democracia, la inclusión y la participación, y para prevenir la desintegración social, la exclusión y la opresión;

- Fomentar acciones comunitarias de educación y desarrollo humano para promover habilidades sociales, cultura comunicativa y para prevenir el aislamiento, la soledad, y malas relaciones entre las personas; $y$

- Mejorar el bienestar social, a través de medios educativos, sobre todo para promover la inclusión y el bienestar social y prevenir la exclusión, la pobreza, la miseria, y los problemas psicosociales (Hämäläinen, 2012).

El alcance de la práctica de la pedagogía social aborda "la duración completa de la vida humana en términos de actividades de educación temprana, juvenil y adulta (interpretado de manera más o menos amplia)" (Hämäläinen, 2012: 9). Concibiendo la educación, como una acción importante de progreso y reforma social, la pedagogía social impregna "el campo educativo de cuestiones sociales y los campos sociales de cuestiones educativas" (Schugurensky \& Silver, 2013). “La pedagogía social considera la educación desde una perspectiva social, al tiempo que las realidades sociales correspondientes son consideradas desde un punto de vista educativo, en tanto que la educación abarca oportunidades para contribuir a la vida social, al bienestar y desarrollo humano" (Hämäläinen, 2012, p. 10).

El campo de trabajo de la pedagogía social se centra en "individuos y grupos que se encuentran en zonas conflictivas de la sociedad, en un campo de tensión entre la integración y la marginación, o incluso la expulsión" (Madsen, 2006, citado en Storø, 2012). Generalmente, la pedagogía social adopta una visión optimista y positiva, basada en los puntos fuertes de la gente que se encuentra en estas circunstancias.

En su raíz ontológica, la pedagogía social (en cada una de sus tres manifestaciones) hace uso de la antropología filosófica. Considera a las personas de todas las edades como sujetos activos, creativos y au-
- enhancing social welfare through educational means, especially with respect to promoting social inclusion and well-being and preventing exclusion, poverty, misery, and psycho-social problems (Hämäläinen, 2012).

The scope of practice of social pedagogy is "the whole human life-span in terms of early, youth, and adult educational (more or less broadly interpreted) activities" (Hämäläinen, 2012, p. 9). Conceiving education as an important method of social progress and reform, social pedagogy concerns itself broadly with "the educational dimension of social issues and the social dimensions of educational issues" (Schugurensky \& Silver, 2013, p. 2). It "views education through social glasses while corresponding social realities are seen from the point of view of education in so far as education addresses opportunities to contribute to social life, welfare and human development" (Hämäläinen, 2012, p. 10).

The subject field of social pedagogy is "individuals and groups who find themselves in conflict zones in society, in the tension field between integration and marginalization or actual expulsion" (Madsen, 2006, as cited in Storø 2012, p. 19). Social pedagogy generally takes a positive, strengthsbased view on people in these circumstances. At its ontological root, social pedagogy (in each of its three manifestations) draws on philosophical anthropology. It holds a view of human nature that sees people of all ages to be active, creative subjects capable of self-education, learning and growth (Hämäläinen, 2012).

Epistemologically, social pedagogy has developed as an interdisciplinary field of many competing theories and paradigms (Hämäläinen, 2012; Schugurensky \& Silver, 2013). It is seen to offer an umbrella framework or broad perspective (Coussée et al., 2010) for thinking about the relationships between education, society, community, and welfare. Social pedagogy can be seen to branch from three trends in modern philosophy of education (i.e., normative, analytical, and critical) with critical social theories providing significant inspiration for theory building and debate (Hämäläinen, 2012). As part of a social scientific basis of social occupations and professions, social 
todidactas, capaces de aprender y desarrollarse (Hämäläinen, 2O12).

Epistemológicamente, la pedagogía social se ha desarrollado como un campo interdisciplinario, apoyándose en teorías y paradigmas enfrentados (Hämäläinen, 2012; Schugurensky \& Silver, 2013). Se considera que ofrece una perspectiva amplia que ayuda a pensar en las relaciones que existen entre educación, sociedad, comunidad y bienestar. (Coussée et al., 2010). La pedagogía social surge de tres ramas de la filosofía moderna de la educación (es decir, normativa, analítica y crítica) y de teorías sociales críticas, proporcionando una inspiración significativa para la construcción de la teoría y del debate (Hämäläinen, 2012). Como parte de una base científica de ocupaciones y profesiones sociales, la pedagogía social está estrechamente conectada a otros campos de las ciencias sociales, como la ética, política, sociología, psicología social. También puede ser considerada como una ciencia de acción, basada en una perspectiva social-constructivista. Al contemplar y tratar a las personas como sujetos creativos y activos, la pedagogía social pretende ayudarlas a que tomen conciencia de sus "oportunidades para influir en sus condiciones de vida.... como individuos, familias, y comunidades" (Hämäläinen, 2012, p. 12). También destaca la importancia de la acción política que lucha por cambiar sistemas y estructuras para mejorar las condiciones de vida y oportunidades para individuos, grupos y comunidades.

Metodológicamente, la pedagogía social no ha desarrollado un enfoque propio; en lugar de ello, aprovecha sobre todo métodos de la pedagogía, incluyendo enfoques comunitarios, basados en actividades y orientados a la experiencia (Schugurensky \& Silver, 2013). El diálogo, la comunalidad y la interacción son principios metodológicos fundamentales, aplicados de forma creativa e innovadora para diferentes grupos.

En definitiva, la pedagogía social consiste más en ética y valores que en métodos y técnicas (EichsteIler \& Holthoff, 2011). Al igual que otras intervenciones sociales y educativas, la pedagogía social podría ser utilizada, y de hecho lo ha sido, en algunos estudios para reproducir relaciones y estructuras sociales regresivas (Lorenz, 2008). Se tiene esta impresión a partir de la revisión de la bibliografía; sin embargo, los métodos de la pedagogía social deben pedagogy is closely connected to other social science domains (e.g., ethics, policy, sociology, social psychology). It can also be viewed as an action-science, based in a social constructivist perspective. In seeing and treating people as creative, active subjects, social pedagogy aims to help make them aware of their "opportunities to...influence their own life conditions...as an individual person, a family, and a community" (Hämäläinen, 2012, p. 12). It also foregrounds the importance of political action that strives to change systems and structures to enhance life conditions and opportunities for individuals, groups and communities.

Methodologically, social pedagogy is not seen to have its own, unique toolbox. Instead, it draws on methods from pedagogy more generally, including community-based, activity-based, and experience-oriented approaches (Schugurensky \& Silver, 2013). Dialogue, communality, and interaction are seen as fundamental methodological principles- applied creatively, innovatively for different groups.

Ultimately, social pedagogy is about ethics and values more than methods and techniques (Eichsteller \& Holthoff, 2011). Similar to other social and educational interventions, social pedagogy could be used - and, in some readings, has been used (e.g., Lorenz, 2008)-to reproduce regressive social relations and structures. One has the sense from the literature, however, the means of social pedagogy should be aligned to the service of empowering oppressed people. Indeed, "in the long run, pedagogical interventions must be accompanied by justice-oriented policies" (Schugurensky \& Silver, 2013, p. 3).

We now turn to our exploration of the interconnections and intersections of social pedagogy and participatory evaluation. 
ser alineados para empoderar a las personas oprimidas. En efecto, "a la larga, las intervenciones pedagógicas deberán estar complementadas con políticas de justicia" (Schugurensky \& Silver, 2013: 3).

\section{Campos enlazados de Teoría y Práctica}

En este apartado, se discuten las intersecciones dinámicas, conceptuales y prácticas que se solapan con enfoques de evaluación participativa y pedagogía social. Previamente, analizamos 121 estudios empíricos sobre evaluación participativa, lo que nos llevó a la detección y desarrollo de siete temas interconectados, basados en campos prácticos relacionales, conceptuales y estructurales (Cousins \& Chouinard, 2012). Los siete temas identificados fueron los siguientes: 1) formación orientada a la participación significativa, 2) proceso relacional y dimensiones de la voz, 3) el trato en contextos multidimensionales, 4) evolución de la identidad, el papel y la posicionalidad del evaluador, 5) selección de stakeholders y consecuencias de la participación, 6) el aprendizaje como base de la práctica y el cambio, y 7) localizaciones relacionales, políticas y discursivas del poder. Posteriormente, reconsideramos nuestro análisis temático, centrándonos en aquellos estudios llevados a cabo en contextos de desarrollo internacional y luego añadimos a nuestra muestra 40 estudios sobre evaluación participativa en desarrollo internacional (Chouinard \& Cousins, 2013; en la prensa). Basándonos en aquellos estudios, observamos cierto solapamiento entre ellos, así como algunas diferencias muy claras en el ámbito del desarrollo internacional (por ejemplo, temas adicionales como características de la participación, requerimientos metodológicos, influencias culturales y creación de capacidades). Aunque no pretendemos revisar estos temas detalladamente, proporcionan el fondo conceptual y comparativo para nuestro análisis de las interconexiones entre pedagogía social y evaluación participativa.

A continuación, comentamos cuatro puntos de enlace -epistemológico, pedagógico, político, y relacional- que surgen de la "lectura" de nuestra investigación sobre evaluación participativa, desde una perspectiva pedagógico-social, a través de la cual poder generar similitudes entre estos dos campos de teoría y práctica.

\section{Intersecting Domains of Theory and Practice}

In this section, we discuss the dynamic conceptual and practical intersections that cut across approaches to participatory evaluation and social pedagogy. In prior research, we analyzed 121 empirical studies on participatory evaluation, leading to the subsequent exploration and development of seven interconnected themes based on relational, conceptual and structural domains of practice (Cousins \& Chouinard, 2012). The seven themes identified were: 1) training leading to meaningful participation, 2) relational process and dimensions of voice, 3 ) dealing with multidimensional contexts, 4) evolution of evaluator identity, role and positionality, 5) stakeholder selection and consequences of participation, 6) learning as a basis for practice and change, and 7) relational, political and discursive locations of power. Subsequently we reconsidered our thematic analysis on the basis of the studies in international development contexts and then augmented our sample with 40 studies on participatory evaluation in international development (Chouinard \& Cousins, 2013; in press). Based on these new analyses, we noted some overlap among studies, as well as some very distinct differences in the international development arena (e.g., additional themes include characteristics of participation, methodological requirements, cultural influences, and learning and capacity building). While we do not intend to revisit these themes in detail here, they provide the conceptual and comparative backdrop to our analysis of the interconnections between social pedagogy and participatory evaluation. In what follows, we discuss four intersecting strands-epistemological, pedagogical, political, and relational-that emerge in 'reading' our research on participatory evaluation through a social pedagogy lens, and through which commonality can be built between these two domains of theory and practice.

In conjoining what are essentially two worlds, participatory evaluation, understood as a largely North American construct in its pragmatic form (P-PE), but with roots of its transformative form (T-PE) in international development in terms, and social pedagogy as a European construct, we note persistent theoretical and practical variation within each. While 
Al combinar lo que son esencialmente dos mundos, por una parte, la evaluación participativa, con enfoque norteamericano en su forma pragmática (EP-P), si bien su forma transformativa (EP-T) tiene sus raíces en la cooperación para el desarrollo internacional; por otra, la pedagogía social como un enfoque europeo, observamos que existen diferencias teóricas y prácticas persistentes en cada uno de ellos. Mientras que ambos enfoques están relacionados con procesos de aprendizaje social, la pedagogía social tiene una historia muy consistente, con una amplia gama de paradigmas y teorías, a menudo contrapuestas, a lo largo de muchas fronteras europeas (Hämäläinen, 2012). La evaluación participativa, por su parte, muestra una multitud de métodos y enfoques, convirtiéndose en una especie de "cajón de sastre", con tendencia a una continua difuminación conceptual y metodológica (Cornwall \& Jewkes, 1995). Nuestra caracterización de ambos conceptos (y cuatro puntos de cruce), aunque quizás menos matizados de lo que podrían estar, pueden ser por lo tanto considerados como heurísticos, diseñados para facilitar la discusión sobre áreas de semejanza, diferenciación y tensión entre ambas vertientes de investigación.

También cabe mencionar que, aunque existe similitud significativa en términos de razón fundamental entre los dos campos de interés, sobre todo en lo referente al enfoque sobre la emancipación a través del autoconocimiento y el aprendizaje, la evaluación participativa de la variante EP-P o EP-T puede servir como función instrumental asociada a la mejora de programas y toma de decisiones organizativas. Además, aunque ambos enfoques están implantados en procesos y prácticas comunitarias, la pedagogía social está mucho más enraizada en el sector del trabajo social, mientras que la evaluación participativa se extiende a numerosos sectores comunitarios, nacionales e internacionales. A este nivel, la pedagogía social tiene lugar en un contexto educativo informal, mientras que la evaluación participativa transcurre en un contexto de programas e intervenciones sociales. Con estas indicaciones en mente, ahora procedemos a comentar los cuatro puntos de cruce de teoría y práctica. both approaches relate to social learning processes, social pedagogy has an incredibly rich history with a range of often competing theories and paradigms across multiple European borders (Hämäläinen, 2012). Participatory evaluation, for its part, signifies multiple methods and approaches, becoming somewhat of a "catch-all concept" prone to persistent conceptual and methodological blurring (Cornwall \& Jewkes, 1995). Our characterization of both concepts (and four intersecting strands), while perhaps less nuanced than it could be, might therefore be considered as a heuristic intended to facilitate discussion about areas of commonality, difference and tension between both streams of inquiry.

It is also worth noting that while there is significant commonality in terms of overall rationale between the two domains of interest, particularly in terms of the mutual focus on emancipation through self-understanding and learning, participatory evaluation of either the P-PE or T$P E$ variety, may ultimately serve an instrumental function related to program improvement and organizational decision making. Moreover, while both approaches are rooted in community-based processes and practices, social pedagogy is very much embedded within the social work sector, while participatory evaluation is situated across multiple community, national and international sectors. At this level, social pedagogy occurs within an informal educational context, whereas participatory evaluation occurs within the context of social programming and interventions. With these caveats in mind, we now turn to our discussion of the four intersecting strands of theory and practice. 


\subsection{Epistemológico}

Ambas, evaluación participativa (en especial EP-T) y pedagogía social, como sistemas de aprendizaje críticos y comunitarios, contrastan con los enfoques educativos positivistas occidentales. En comparación con posturas de objetividad y neutralidad que se observan claramente en enfoques más positivistas, los pedagogos y evaluadores sociales comparten actitudes similares de compromiso y autorreflexión, como parte clave del proceso de aprendizaje. Dada la sólida tradición emancipatoria, los profesionales desempeñan, en gran medida, el papel de expertos y procuradores de procesos, así como de educadores y profesores en el contexto de su trabajo. Además, con fuertes raíces multidisciplinarias, ambos enfoques tienen su base en la noción de la "ciencia de la acción", mientras que los profesionales "pioneros" (Trickett \& Espino, 2004) abarcan ambos mundos de teoría y práctica. Esta orientación común de teoría puede ser rastreada hasta las nociones de práctica de Freire (1970), como forma de pedagogía crítica (reflexión y acción para iniciar el cambio) y “la investigación-acción" de Lewin (1946), integrando acción, investigación y reflexión en un contexto de colaboración. Aunque observamos fuertes conexiones teóricas, detectamos diferencias entre los dos enfoques. La evaluación participativa está más bien orientada al diseño de un proceso de evaluación, cuyo objetivo es el cambio social y la emancipación, y la pedagogía social está más bien enfocada al proceso de aprendizaje social.

Como sistemas de aprendizaje social, ambos enfoques comparten una epistemología social constructivista, en la que el conocimiento es activamente co-generado entre profesionales y participantes. Si bien existe un solapamiento significativo a la hora de conceptualizar el aprendizaje como proceso social, las perspectivas sobre "lo social", y por tanto sobre cómo el conocimiento es en última instancia generado, parecen diferir. Los stakeholders involucrados en una evaluación participativa a menudo reflejan bases culturales diversas, resultando en muchas ocasiones en conflictos de poder y privilegio. Desde esta perspectiva, la co-producción del conocimiento no se genera sola, y hay que centrar las actividades de manera deliberada en la creación de relaciones. Al mismo tiempo, en base a nuestra investigación so-

\subsection{Epistemological}

Both participatory evaluation (especially T-PE) and social pedagogy, as critical, community-based learning systems, stand in sharp contrast to standard positivist, Western-based educational approaches. In contrast to stances of objectivity and neutrality that one would see in more positivist approaches, social pedagogues and evaluators share similar attitudes of engagement and self-reflection as a key part of the learning process. Given the strong emancipatory tradition, practitioners are very much in the role of process experts and facilitators, as well as educators and teachers within the context of their work. Moreover, with strong multidisciplinary roots, both approaches are grounded in the notion of "action science", whereas "boundary spanners" (Trickett \& Espino, 2004) practitioners straddle the worlds of both theory and practice. This common theoretical orientation can be traced back to Freire's (1970) notion of praxis as a form of critical pedagogy (reflection and action to initiate change) and Lewin's (1946) "action research" integrating action, research and reflection in a collaborative context. While we note strong theoretical connections, we nonetheless discern differences between the two approaches, with participatory evaluation more likely oriented towards designing an evaluation process leading to social change and emancipation, and social pedagogy more focused on the social learning process itself.

As social learning systems, both approaches also share a social constructivist epistemology, where knowledge is actively co-constructed between practitioners and participants. While there is significant overlap in terms of conceptualizing learning as a social process, perspectives on "the social", and hence on how knowledge is ultimately constructed, seems to differ. Stakeholders involved in a participatory evaluation often reflect culturally diverse backgrounds, oftentimes resulting in issues of power and privilege. From this perspective, the co-construction of knowledge is not a given, as the focus on relationships becomes a very deliberate activity. At the same time, based on our exploration of social pedagogy, we found little in the literature to suggest tension between practitioners and participants, or even among participants themselves, a fact that may 
bre la pedagogía social, encontramos muy poco en la literatura que sugiera tensión entre profesionales y participantes, o incluso entre los propios participantes, un hecho que podría reflejar las bases lógicas de la inclusión. Volveremos a este asunto en nuestra discusión sobre la vertiente relacional.

\subsection{Pedagógico}

Ambas, la pedagogía social y la evaluación participativa pueden ser definidas como procesos fundamentalmente educativos, con un fuerte énfasis en autorreflexión, co-aprendizaje, resolución de problemas y emancipación. Para ambas, el aprendizaje está considerado como una dimensión de práctica social (Lave \& Wenger, 1991), ya que ambos, profesionales y aprendices (o participantes) trabajan dialógicamente en conjunto para co-generar el texto narrativo (Long, 1992). Es a través del proceso de participación y la propia interacción social por lo que el aprendizaje tiene lugar. Según Hämäläinen (2012), "el diálogo, la comunalidad y la interacción están a menudo considerados como principios metodológicos básicos" (p. 12). Ambos enfoques están también centrados en la educación, no únicamente desde la perspectiva individual o comunitaria, sino también desde la perspectiva más amplia de la sociedad. El papel del individuo, como crítico, emancipado y más culto, es uno de los objetivos críticos del aprendizaje (Eichsteller \& Hosthoff, 2011). La evaluación participativa se centra en el aprendizaje a nivel individual, así como en el aprendizaje que se extiende más allá de las exigencias del contexto inmediato, para incluir cambios de comportamiento, actitud o efecto a nivel de grupo, organización o comunidad. Este aprendizaje se conoce como “" process use" (Patton, 2008), ya que ocurre como resultado de la participación en el proceso de evaluación, es decir, a través de la participación de los stakeholders (hasta cierto punto) en el diseño, la recolección de datos, el análisis y el informe. Y es precisamente el aprendizaje el que tiene lugar durante este proceso de evaluación que conecta ambas, evaluación participativa y pedagogía social, en su potencial emancipatorio y transformativo.

Aunque ambos enfoques pueden ser definidos como sistemas educativos, la pedagogía social se centra de forma más directa en el proceso de apren- reflect the different rationales for inclusion. We will reprise this issue in our discussion of the relational strand.

\subsection{Pedagogical}

Both social pedagogy and participatory evaluation can be defined as fundamentally educational processes, with a strong emphasis on self-reflection, colearning, problem solving and emancipation. For both, learning is considered a dimension of social practice (Lave \& Wenger, 1991), as both practitioners and learners (or participants) work together dialogically to co-construct the narrative text (Long, 1992). It is through the process of participation, and through the process of social interaction itself, that learning takes place. According to Hämäläinen (2012), "dialogue, communality and interaction are often seen as basic methodological principles" (p. 12). Both approaches are also focused on education, not only from the perspective of the individual or community, but also from the perspective of the broader society. The individual's role, as critical, emancipated and more enlightened, becomes one of the critical aims of learning (Eichsteller \& Hosthoff, 2011). Participatory evaluation is focused on learning at the individual level, as well as on learning that extends beyond the exigencies of the immediate context, to include group, organizational or community-level changes in behaviour, attitude or effect. This learning is termed "process use" (Patton, 2008), as it occurs as a result of participation in the evaluation process, that is, through stakeholder involvement (to some extent) in design, data collection, analysis and reporting. And it is precisely the learning that occurs during this evaluation process that connects both participatory evaluation and social pedagogy to their emancipatory and transformative potentials.

While both approaches can be defined as learning systems, social pedagogy has a more direct focus on the learning process and on its potential for change at the individual and societal levels. Learning, while still a defining characteristic of participatory evaluation, is not the primary focus of the process, but a by-product of participation itself. Despite these 
dizaje y en su potencial de cambio, a nivel individual y social. El aprendizaje, siendo una característica definitoria de la evaluación participativa, no es el núcleo primario del proceso, sino un derivado de la propia participación. Pese a estas leves diferencias a nivel pedagógico, ambos enfoques comparten muchos de los valores de la pedagogía crítica, entre los cuales encontramos, principalmente, la creencia en la centralidad de la educación a la hora de determinar relaciones sociales y políticas y abordar desigualdades sociales (Giroux, 2005). La pedagogía crítica también se ve muy influida por los trabajos de Paulo Freire y John Dewey a la hora de elaborar un abordaje de la educación como práctica moral y política, y cuando se trata de conectar un enfoque crítico sobre el aprendizaje con su potencial transformativo y emancipatorio.

\subsection{Político}

Dada la naturaleza del proceso pedagógico y su enfoque hacia el cambio social, ambas, pedagogía social y evaluación participativa, pueden ser consideradas prácticas políticas (Cameron \& Moss, 2011; Gaventa, Creed \& Morrissey, 1998). Ambos enfoques desafían dominios tradicionales de poder en sus respectivos campos, en lugar de conservar modelos de status quo educativo. Se centran en quiénes están involucrados en el proceso (qué stakeholders están incluidos, qué grupos de gente), y cómo están involucrados (hasta qué punto están involucrados). En ambas, pedagogía social y evaluación participativa, las personas no están consideradas como meros receptáculos a la espera de ser llenados, sino como participantes activos involucrados en el proceso de diálogo del aprendizaje y generación de conocimiento. Desde esta perspectiva, a las personas se las tiene en cuenta más como agentes que como objetos.

El vínculo entre educación y cambio social es profundo, ya que ambos comparten raíces con teóricos, como Paulo Freire y la investigación- acción de la década de los 70 del siglo XX (Brisolara, 1998; Hämäläinen, 2012). Si bien, estos enfoques también comparten objetivos críticos, asociados a ayudar a los menos poderosos, mejorando la vida de las personas y el desarrollo de la comunidad (Brisolara, 1998; Lorenz, 2008;), la base lógica de la evaluación par- subtle variances at the pedagogical level, both approaches share many of the values also found in critical pedagogy, primary among which is a belief in the centrality of education in determining political and social relations and in addressing societal inequities (Giroux, 2005). Critical pedagogy also borrows heavily from Paulo Freire and John Dewey in articulating an approach to education as a moral and political practice, and in connecting a critical approach to learning with its transformative and emancipatory potential.

\subsection{Political}

Given the nature of the pedagogic process and focus on social change, social pedagogy and participatory evaluation can both be considered political practices (Cameron \& Moss, 2011; Gaventa, Creed \& Morrissey, 1998). Both approaches challenge traditional domains of power within their respective fields, rather than with maintaining models of educative status quo. The focus is on who is involved in the process (which stakeholders are included, which groups of people), and how they are involved (the depth of their involvement). In both social pedagogy and participatory evaluation, people are not considered mere receptacles waiting to be filled, but active participants involved in the dialogic process of learning and knowledge creation. From this perspective, people are characterized as agents rather than as objects.

The link between education and social change run deep, as both share roots with theorists such as Paulo Freire and action research from the 1970s (Brisolara, 1998; Hämäläinen, 2012). While both approaches also share critical aims related to helping the least powerful, improving people's lives and building community (Brisolara, 1998; Lorenz, 2008;), the rationale for participatory evaluation is directly focused in addressing issues of power and privilege. As Brisolara (1998) notes, "the possibility of emancipatory social change is predicated on an intimate 
ticipativa está directamente centrada en el abordaje de asuntos de poder y privilegio. Como estipuló Brisolara (1998), "la posibilidad de cambio social emancipatorio está basada en la profunda comprensión de las relaciones de poder y la manipulación premeditada de las mismas" (p. 31). La pedagogía social, por su parte, parece combinar la búsqueda de soluciones educativas para mitigar problemas sociales, bien abordando diferencias de poder como base lógica primaria o como medidas de adaptación para tratar problemas sociales.

Una de las diferencias más obvias, al menos políticamente, entre los dos enfoques, se encuentra en sus respectivas relaciones con el estado. Si bien la evaluación de programas, como instrumento imparcial y neutral que proporciona información objetiva basada en pruebas para satisfacer los requisitos primarios de rendición de cuentas, se considera metodológicamente creíble, dentro de la mayoría de los contextos de sectores públicos nacionales y federales, los enfoques participativos sensibles a necesidades comunitarias no están considerados de esa manera (Chouinard, 2013). La tensión está entre las evaluaciones que favorecen enfoques tecnocráticos e instrumentales y aquellas con un enfoque más humano, que incorporan conocimiento comunitario local. La pedagogía social, por su parte, parece tener fuertes raíces institucionales y comunitarias, dada su historia como parte de la maquinaria del estado en Alemania (Smith, 2012), y su consecuente profesionalización y papel en trabajo social en diversos países de Europa (Smith \& White, 2013) y en el sector de educación en América Latina (Ucar, 2012).

\subsection{Relacional}

Ambas, pedagogía social y evaluación participativa son enfoques fundamentalmente basados en las interacciones y relaciones que se producen entre los profesionales y los participantes. La pedagogía social surge de la relación que se genera entre profesionales y participantes, ya que las relaciones se consideran la base de la educación (Eichsteller \& Hosthoff, 2011). Al contrario que la evaluación participativa, en la cual las relaciones, aunque esenciales, pueden ser tomadas como medio para un fin, éstas, desde una perspectiva pedagógica-social, son understanding and wilful manipulation of power relations" (p. 31). Social pedagogy, for its part, seems to combine a focus on finding educational solutions to ameliorate social problems, either addressing power differentials as a primary rationale or as adaptive measures for addressing social problems.

One of the most obvious differences at least politically between the two approaches, is in their respective relationships to the state. While program evaluation as an impartial, neutral instrument providing objective and evidence-based information to satisfy what are primarily accountability requirements is considered methodologically credible within most national and federal public sector contexts, participatory approaches that are sensitive and responsive to community-based needs, are not (Chouinard, 2013). The tension is between evaluations that favour technocratic and instrumental approaches and those that are more human-centred and incorporate local community knowledge. Social pedagogy, for its part, appears to have stronger institutional and communitybased roots, given its history as part of the state apparatus in Germany (Smith, 2012) and its subsequent professionalization and role in social work in parts of Europe (Smith \& White, 2013) and in the education sector in Latin America (Ucar, 2012).

\subsection{Relational}

Both social pedagogy and participatory evaluation are fundamentally relational approaches grounded in the interactions and relationships that are formed between practitioners and participants. Social pedagogy is brought to life through the relationship that is developed between practitioners and participants, as relationships are considered to be the basis of education (Eichsteller \& Hosthoff, 2011). In contrast to participatory evaluation where relationships, while essential, can be pursed as a means to an end, relationships from a social pedagogic perspective, are 
fines en sí mismas. Estas relaciones pueden ser comprendidas a nivel epistémico, desde una perspectiva social constructivista en la que el conocimiento generado es el resultado de las interacciones sociales; y a nivel político, en cuanto a las interrelaciones entre las personas involucradas en el proceso de aprendizaje (Cousins \& Chouinard, 2012). Aunque vemos similitudes a nivel epistémico en lo referente a la generación de conocimiento, existen diferencias a nivel político, probablemente basadas en la naturaleza de "valoración" y "juicio" de la evaluación, así como en la inclusión de una variedad de intereses, necesidades, asuntos de poder y privilegio de los stakeholders, que son diversos y a menudo opuestos.

Constatamos que muchos de estos puntos de intersección entre la pedagogía social y la evaluación participativa están en la misma línea que la EP-T, pero no de forma exclusiva. Claramente, éste es el caso desde la perspectiva de aprovechar el cambio social a través de procesos educativos. Sin embargo, también compartido a cierto nivel, está el compromiso con la solución práctica de problemas, como un medio para generar el cambio. Esto es sin duda el caso de EP-P, y vemos algunas conexiones distintas, aunque matizadas, con la pedagogía social. Dados estos puntos de cruce y separación entre estas dos vertientes de investigación, procedemos a comentar algunos asuntos dignos de ser considerados, con el fin de generar un diálogo con gran potencial de beneficio mutuo.

\section{Consideraciones finales}

En este último apartado, abrimos un diálogo exploratorio entre la pedagogía social y la evaluación participativa; dos campos de investigación que, en nuestra opinión, comparten una serie de afinidades a nivel filosófico, teórico y práctico. Basándonos en nuestra comprensión formativa de la pedagogía social, analizamos qué puede ésta aportar a la evaluación participativa. Basándonos en nuestra comprensión formativa de la pedagogía social, analizamos qué puede ésta aportar a la evaluación participativa, así como qué lecciones podemos aprender de las prácticas de la pedagogía social, analizamos qué puede ésta aportar a la evaluación participativa, así como qué lecciones podemos aprender de las prácticas ends in themselves. These relationships can be understood at the epistemic level, from a social constructivist perspective where the knowledge that is created is a result of social interactions, and at the political level, in terms of the inter-relationships among people involved in the learning process (Cousins \& Chouinard, 2012). While we see similarities at the epistemic level in terms of knowledge construction, there are differences at the political level likely, based on the 'assessment' and 'judgement' oriented nature of evaluation, as well as on the inclusion of multiple, diverse, and often conflicting stakeholder interests, needs and issues of power and privilege.

We can see that many of the points of intersection between social pedagogy and participatory evaluation are aligned with the T-PE agenda, yet this is not exclusively the case. Clearly this is the case from the perspective of leveraging social change through educative processes. Yet, also shared at some level, is a commitment to practical problem solving as a means to bring about change. This is undeniably the case with P-PE and we see some distinct, albeit nuanced, connections to social pedagogy. Given these points of intersection and separation between these two streams of inquiry we now turn to some issues for consideration by way of opening a conversation that holds great potential for mutual benefit.

\section{Issues for Consideration}

In this final section, we open up an exploratory dialogue between social pedagogy and participatory evaluation, two fields of inquiry that we believe share a number of affinities at the philosophical, theoretical and practical levels. Based on our formative understanding of social pedagogy, we explore what it can bring to participatory evaluation, as well as what lessons we might learn from social pedagogic practices. While we acknowledge differences in historical formation and overall rationale for inquiry, as well as areas of some tension between the two approaches, we believe that there are significant areas of commonality and intersection to merit further discussion at the le- 
de la pedagogía social. Si bien detectamos diferencias entre los dos enfoques, respecto a la formación histórica y la base lógica general para la investigación, así como áreas de cierta tensión, creemos que hay áreas significativas de similitud y enlace que merecen ser discutidas en mayor profundidad a nivel de teoría y práctica. Específicamente, exponemos tres asuntos a ser considerados.

En primer lugar, en la evaluación participativa, el aprendizaje es a menudo el resultado de la participación en el proceso de evaluación, en cuanto al nivel y la intensidad del compromiso en el diseño, recolección de datos, análisis e informe de los hallazgos de la evaluación. Si bien se proporciona una formación directa a los stakeholders para hacer posible su participación en el proceso de evaluación (a menudo a través de talleres, coaching o actividades de aprendizaje en el trabajo), gran parte del aprendizaje que tiene lugar fuera de la vertiente práctica y técnica es resultado de la participación en el proceso de evaluación (es decir, "process use").

El aprendizaje, a partir del "process use", tiene lugar a nivel individual, de grupo y de organización/comunidad, lo que lleva a cambios en la acción, el comportamiento, la actitud o el efecto, así como en el aprendizaje organizativo (Amo \& Cousins, 2007). Si bien estos resultados del aprendizaje son a menudo deliberados en EP-T, en EP-P, habitualmente se consideran efectos secundarios o fortuitos de la propia evaluación, probablemente debido a las diferencias en la base lógica para la inclusión. Por ejemplo, la evaluación participativa práctica adopta un enfoque pragmático de la evaluación, centrado en el uso de hallazgos para la toma de decisiones de un programa, una política o una organización. Como tales, los resultados del aprendizaje tienen mayor tendencia a adoptar una forma instrumental relacionada con la toma de decisiones y la resolución de problemas, así como formas conceptuales asociadas a una mejor comprensión y percepción del programa (Patton, 2008). En la evaluación participativa transformadora, la evaluación tiene una imperativa ideológica relacionada con el empoderamiento de los participantes para que produzcan su propio conocimiento, como una forma de abordar asuntos de poder y privilegio y, en definitiva, para mejorar sus vidas. El aprendizaje es pues más deliberado y centrado, a través de la evaluación, vel of theory and practice. Specifically, we raise three issues for consideration.

First, in participatory evaluation, learning is often the result of participation in the process of evaluation, in terms of level and depth of involvement in the design, data collection, analysis, and reporting of evaluation findings. While there is direct training provided to stakeholders to enable meaningful participation in the evaluation process (often through workshops, coaching or on-the-job activities), much of the learning that occurs outside of the practical and technical stream is the result of participation in the evaluation process (i.e., process use). Learning from process use occurs at the individual, group and organizatio$\mathrm{nal} /$ community level, leading to changes in action, behaviour, attitude or effect, as well as in organizational learning (Amo \& Cousins, 2007). While these learning outcomes are often deliberate in T-PE, in P-PE they are often secondary or incidental to the evaluation itself, likely due to differences in rationales for inclusion. For example, practical participatory evaluation takes a pragmatic approach to evaluation that is focused the use of findings for program, policy or organizational decision making. As such, learning outcomes are more likely to take an instrumental form related to decision making and problem solving, as well as conceptual forms related to increased understanding and program insight (Patton, 2008). In a transformative participatory evaluation, evaluation has an ideological imperative related to empowering participants in constructing their own knowledge as a way to address issues of power and privilege and ultimately ameliorate their lives. Learning is thus more deliberate and focused throughout the evaluation, as participation in the process of the evaluation leads to social and political change. Given the emphasis on the learning process as a dimension of social practice within the stream of social pedagogy, participatory evaluation has much to learn about the social learning process. What can an understanding of social pedagogy bring to participatory evaluation that will solidify the learning that is often a mere by-product of participation? In other words, what can be learnt from social pedagogy about the social learning process? 
ya que la participación en el proceso de la evaluación conduce al cambio social y político. Dado el énfasis en el proceso de aprendizaje, como campo de práctica social dentro de la vertiente de la pedagogía social, la evaluación participativa tiene mucho que aprehender del proceso de aprendizaje social. ¿Qué puede aportar la comprensión de la pedagogía social a la evaluación participativa, que sea capaz de solidificar el aprendizaje, a menudo un mero derivado de la participación? En otras palabras, ¿̇qué puede aprenderse de la pedagogía social acerca del proceso de aprendizaje social?

La segunda consideración está relacionada con un abordaje significativo de 'lo social ' y las relaciones. Dentro del discurso de la pedagogía social, la discusión parece mantenerse a un nivel bastante macro-político, al menos desde una perspectiva histórica, como parte del aparato estatal y preocupaciones en torno a asuntos de profesionalización predominante (Lorenz, 2008). La evaluación participativa, por otra parte, proporciona una noción problemática de 'lo social', basada en el énfasis en las interacciones sociales a nivel micropolítico, en el cual los asuntos de procesos están asociados con la inclusión de stakeholders, cuyas opiniones, experiencias, necesidades y aportes de conocimiento, frecuentemente, generan conflictos significativos que a menudo no pueden ser resueltos de manera satisfactoria, particularmente en el interés de personas y grupos marginados (ver, por ejemplo, una excelente ilustración de Greene, 2000). Dado el enfoque basado en proporcionar soluciones educativas frente a procesos propensos a conflictos micro-políticos, interpersonales o grupales para abordar problemas sociales, combinado con una perspectiva política más amplia, nos preguntamos si ¿puede la pedagogía social ofrecer otra perspectiva mediante la cual tratar la política, a menudo involucrada en enfoques participativos de la evaluación?

Por último, como enfoques fundamentalmente basados en una epistemología social constructivista, ambas, pedagogía social y evaluación participativa, aportan necesariamente un abordaje relacional a su trabajo. En una evaluación participativa, diferentes stakeholders son invitados a trabajar activamente en conjunto para diseñar el proceso de evaluación, recoger y analizar los datos. Cuanto más diversos sean
A second issue for consideration relates to a significant focus on the 'social' and on relationships. Within social pedagogical discourse, discussion seems to remain at a fairly macro-political level, at least from a historical perspective, as part of the state apparatus and concerns around issues of professionalization predominate (Lorenz, 2008). Participatory evaluation, on the other hand, provides a problematized notion of the 'social', based on its emphasis on social interactions at the micropolitical level, where process issues relate to stakeholder inclusion and questions about whose views, experiences, needs and knowledge inputs frequently generate significant conflict that often cannot be satisfactorily resolved, particularly in the interests of marginalized people and groups (see for example, an excellent illustration by Greene, 2000) Given the focus on providing educational solutions versus processes that are prone to micro-politics and interpersonal or group conflict to address social problems, coupled with a broader political perspective, can social pedagogy offer another lens in which to approach the politics often involved in participatory approaches to evaluation?

Finally, as approaches that are fundamentally grounded in a social constructivist epistemology, both social pedagogy and participatory evaluation necessarily bring a relational focus to their work. In a participatory evaluation, diverse stakeholders are encouraged to actively work together to design the evaluation process, and collect and analyze the data. The more diverse the stakeholder groups, the greater the potential for conflict and the higher likelihood that issues of power will prevail among participants and local community groups, helping to circumscribe whose voices are heard and what they can or cannot say. In her critical analysis of participatory processes Gregory (2000) argues such processes, in the context of inherently political contexts, run the risk of having precisely the opposite effect than intended. Given consistent work with diverse populations, social pedagogy likely has much to offer participatory evaluation in terms of accommodating what are often marginalized populations. How does social pedagogy facilitate group and social learning processes? What types of cha- 
los grupos de participantes, mayor es la probabilidad de conflicto y la posibilidad de que predominen asuntos de poder entre los participantes y grupos comunitarios locales, lo que ayuda a delimitar las voces de quién son escuchados y qué pueden o no decir. En su análisis crítico de los procesos participativos, Gregory (2000) comenta que dichos procesos, en lo referente a contextos inherentemente políticos, conllevan el riesgo de tener precisamente el efecto contrario al deseado. Considerando el trabajo consistente con poblaciones diversas, la pedagogía social tiene más bien mucho que ofrecer a la evaluación participativa en lo referente a ayudar a lo que a menudo son poblaciones marginadas. ¿De qué manera la pedagogía social facilita los procesos de aprendizaje grupal y social? ¿A qué tipo de desafíos se enfrentan y cómo los abordan?

\section{Conclusiones}

Trabajando desde la intuición, de que la evaluación participativa y la pedagogía social comparten algunas afinidades conceptuales y prácticas, formulamos al principio de este artículo: “chasta qué punto y de qué manera puede la teoría y la práctica de la evaluación participativa beneficiarse de un análisis comparativo con la pedagogía social?". Nuestro enfoque, como especialistas en evaluación participativa, abordado desde un contexto norteamericano era, en primer lugar, ofrecer una descripción de nuestra comprensión formativa de la pedagogía social, y posteriormente utilizarla como perspectiva a través de la cual revisar nuestro conocimiento más meticulosamente de la base teórica y práctica de la evaluación participativa. Este enfoque comparativo, nos ha permitido 'ver' algunas de las afinidades y diferencias principales entre los dos campos, a lo largo de las líneas epistemológica, pedagógica, relacional y política.

Al probar un nuevo par de gafas, por primera vez, la vista es a menudo imperfecta. Por lo tanto, lo que hemos descrito aquí puede que sea algo impreciso. No obstante, nuestro análisis comparativo sugiere que el campo de la evaluación participativa podría beneficiarse de la creación de vínculos que podrían conducir a un diálogo constante y con aquellas personas que trabajan en pedagogía social. Este artículo representa un paso inicial en esta dirección. Nues- llenges do they encounter and how do they address them?

\section{Concluding Thoughts}

Working from the intuition that participatory evaluation and social pedagogy shared some conceptual and practical affinities, we asked at the outset of this paper 'to what extent and how can participatory evaluation theory and practice benefit from a comparative analysis with social pedagogy?' Our approach as specialists in participatory evaluation working from a North American context was, first, to offer a description of our formative understanding of social pedagogy and then to use this as a lens through which to re-view our more thorough knowledge of the theoretical and practical bases of participatory evaluation. This comparative approach allowed us to 'see' some of the main affinities and differences between the two fields along epistemological, pedagogical, relational, and political lines. When trying on a new pair of glasses for the first time, one's vision is often imperfect. There may therefore be some imprecision in what we have described. Nonetheless, our exploratory comparative analysis suggests that the field of participatory evaluation could benefit from forging linkages that could lead to a sustained dialogue and with those working in social pedagogy. This article represents an initial step in this direct. Our analysis suggests that a starting point for such a dialogue could be on the topic of creating more socially pedagogic forms of participatory evaluation. Three potential lines of dis- 
tro análisis sugiere que un punto de inicio para dicho diálogo podría estar en la creación de formas de evaluación participativa más pedagógicosociales. Tres líneas potenciales de discusión podrían incluir: 1) cómo la teoría y la práctica del aprendizaje social desde la tradición de la pedagogía social pueden tomar parte en los procesos de aprendizaje de enfoques participativos de la evaluación; 2) cómo la perspectiva macro-política y las soluciones educativas que se han desarrollado en pedagogía social pueden ayudar a juzgar los conflictos micro-políticos en procesos de evaluación participativa; 3) cómo la ayuda a poblaciones marginadas en enfoques pedagógicosociales puede facilitar el abordaje de asuntos de poder y privilegio en procesos de evaluación participativa.

Finalizamos expresando nuestra opinión de que se pueden obtener beneficios, dentro de la comunidad de la pedagogía social, a la hora de comprometerse con aquellas personas involucradas en evaluación participativa. En particular, podría parecer que las formas participativas de la evaluación ofrecen enfoques evaluativos coherentes con la filosofía y los objetivos subyacentes a la práctica de la pedagogía social. Sin embargo, como abrimos este análisis con el objetivo de crear una comprensión mutua, no queremos imponer nuestra opinión sobre lo que nuestros interlocutores en la comunidad de la pedagogía social deberían pensar, al respecto. Ahora que el canal dialógico queda abierto, con este primer movimiento, esperamos que un fructuoso diálogo en nuestros respectivos campos continúe, generando un beneficio mutuo. cussion might include: 1) how social learning theory and practice from within the social pedagogy tradition can inform and potentially learning processes in participatory approaches to evaluation; 2) how the macro-political perspective and educational solutions that have been developed in social pedagogy may help adjudicate micro-political conflicts in participatory evaluation processes; 3) how the accommodation of marginalized populations in social pedagogy approaches can help address issues of power and privilege in participatory evaluation processes.

We should end by acknowledging that there likely are benefits to be gained within the social pedagogy community in engaging with those involved in participatory evaluation. In particular, participatory forms of evaluation would seem to offer evaluative approaches that are congruent with the underlying philosophy and aims of social pedagogic practice. However, as we opened this exploration in the spirit of building mutual understanding, we would not want to impose our views about what our interlocutors in the social pedagogy community should think in this regard. Now that the dialogic channel is open, with this first gambit, we hope a fruitful dialogue across our respective fields will continue, resulting in mutual benefit.

\section{Referencias bibliográficas/Bibliographic References}

Amo, C. \& Cousins, J. B. (2007). Going through the process: An examination of the operationalization of process use in empirical research on evaluation. In J. B. Cousins (Ed.), Process use in theory, research and practice. New Directions for Evaluation.No. 116 (pp. 5-26). San Francisco: Jossey-Bass.

Brisolara, S. (1998). The history of participatory evaluation and current debates in the field.In E. Whitmore (Ed.), Understanding and practicing participatory evaluation. New Directions in Evaluation, No. 80 (pp. 25-41). San Francisco: Jossey Bass.

Cameron, C. \& Moss, P. (2011). Social pedagogy: Understandings and opportunities. In C. Cameron \& P. Moss (Eds.), Social pedagogy and working with children and young people. (pp. 7-32). London: Jessica Kingsley Publishers.

Cameron, C., Petrie, P. Wigfall, V., Kleipoedszus, S. \& Jasper, A. (2011). Final report of the social pedagogy pilot programme: development and implementation. . London: Institute of Education. Available online: http://www.ioe.ac.uk/study/departments/tcru/4804.html. 
Chouinard, J. A. (2013). The case for participatory evaluation in an era of accountability.American Journal of Evaluation, 34(2), 237-253.

Chouinard, J. A. \& Cousins, J. B. (2013). Participatory evaluation for development: Examining research-based knowledge from the African perspective.African Evaluation Journal, 1(1), 1-19.

Chouinard, J. A. \& Cousins, J. B. (in press). The journey from rhetoric to reality: Participatory evaluation in a development context. Educational Assessment, Evaluation and Accountability.

Cornwall, A. \& Jewkes, R. (1995). What is participatory research? Social Science and Medicine, 41(12), 16671676.

Cousins, J. B. (2007).Process use in theory, resesarch and practice.New Directions for Evaluation. No. 116. SanFrancisco: Jossey Bass.

Cousins, J. B. \& Chouinard, J. (2012).Participatory evaluation up close: A review and integration of research-based knowledge. Charlotte NC: Information Age Press.

Cousins, J. B. \& Earl, L. M. (1992).The case for participatory evaluation.Educational Evaluation and Policy Analysis, 14(4), 397-418.

Coussée, F., Bradt, L., Roose, R. \&Bouverne-De Bie, M. (2010).The emerging social pedagogical paradigm in UK child and youth care: Deus ex machina or walking the beaten path? British Journal of Social Work, 40, 789-805.

Eichsteller, G. \&Holzhoff, S. (2011a). Conceptual foundations of social pedagogy: A transnational perspective from Germany. . In C. Cameron \& P. Moss (Eds.), Social pedagogy and working with children and young people. (pp. 33-52). London: Jessica Kingsley.

Eichsteller, G. \& Holzhoff, S. (2011b). Social pedagogy as an ethical orientation towards working with people - historical perspectives. . Children Australia, 36.(4), 176-185.

Eriksson, L. \& Markström, A.-M. (2003). Interpreting the concept of social pedagogy. . In A. Gustavsson, H.E. Hermansson \& J. Hämäläinen (Eds.), Perspective and theory in social pedagogy (pp. 9-23). Göteborg: Daidalos.

Fetterman, D. \&Wandersman, A. (Eds.). (2005). Empowerment evaluation principles in practice. New York: Guilford.

Friere, P. (1970). Pedagogy of the oppressed. New York: Seabury Press.

Gaventa, J., Creed, V. \& Morrissey, J. (1998). Scaling up: Participatory monitoring and evaluation of a federal empowerment program. In E. Whitmore (Ed.), Understanding and practicing participatory evaluation.New Directions in Evaluation, No. 80 (pp. 81-94). San Francisco: Jossey Bass.

Giroux, H.A. (2005). Border crossings: Cultural workers and the politics of education.New York, NY: Routledge.

Greene, J. (2000). Challenges in practicing deliberative democratic evaluation. In K. E. Ryan \& L. DeStefano (Eds.), Evaluation as a democratic process: Promoting inclusion, dialogue, and deliberation No. 85 (pp. 27-38). San Francisco: Jossey-Bass.

Gregory, A. (2000). Problematizing participation. Evaluation, 6(2), 179-199.

Hämäläinen, J. (2003). The concept of social pedagogy in the field of social work.Journal of Social Work, $3(1), 69-80$.

Hämäläinen, J. (2012). Social pedagogical eyes in the midst of diverse understandings, conceptualisations and activities. . International Journal of Social Pedagogy, 7(1), 3-16.

Katz, S., Sutherland, S. \& Earl, L. (2002). Developing an evaluation habit of mind. Canadian Journal of Program Evaluation, 17(2), 103-119.

Koengeter, S. \& Schroeer, W. (2013). Variations of social pedagogy - Explorations of the transnational settlement movement. Educational Policy Analysis Archives, 27(42), 1-21.

Lave, J. \& Wagner, E. (1991). Situated learning: Legitimate peripheral participation. New York: Cambridge University Press.

Lewin, K. (1946). Action research and minority problems. . Journal of Social Issues 2(4), 34-46. 
Long, N. (1992). Battlefields of knowledge: The interlocking of theory and practice in social research and development. In N. Long \& A. Long (Eds.), (pp. 3-43). London: Routledge.

Lorenz, W. (1994). Social work in a changing Europe London: Routledge.

Lorenz, W. (2008). Paradigms and politics: Understanding methods paradigms in an historical context: The case of social pedagogy. British Journal of Social Work, 38 625-644. .

Oakley, P. (1991). Projects with people: The practice of participation in rural development. Geneva: International Labour Organisation.

Patton, M. Q. (1998). Discovering process use. Evaluation, 4, 225-233.

Patton, M. Q. (2008).Utilization-focused evaluation (4th ed.). Thousand Oaks, CA: Sage.

Schugurensky, D. (2011). Paulo Freire. New York: Continuum.

Schugurensky, D. \& Silver, M. (2013). Social pedagogy: Historical traditions and transnational connections. Education Policy Analysis Archives, 21(35), 1-16.

Schwandt, T. (2003). "Back to the rough ground!" Beyond theory to practice in evaluation.Evaluation, 9(3), 353-364.

Smith, M. \& Whyte, B. (2008). Social education and social pedagogy: Reclaiming a Scottish tradition in social work.European Journal of Social Work, 11(1), 15-28.

Smith, M. K. (2012). Social pedagogy: The development of theory and practice. Encyclopaedia of Informal Education. Retrieved November 20, 2013, from http://infed.org/mobi/social-pedagogy-the-development-of-theory-and-practice.

Smith, M. K. (2012). Social pedagogy: the development of theory and practice. In the encyclopaedia of informal education. Retrieved November 20, 2013, from http://infed.org/mobi/social-pedagogy-thedevelopment-of-theory-and-practice.

Storø, J. (2012). The difficult connection between theory and practice in social pedagogy.International Journal of Social Pedagogy, 7(1), 17-29.

Trickett, E. J. \& Ryerson-Espino, S. L. (2004). Collaboration and social inquiry: Multiple meanings of a construct and its role in creating useful and valid knowledge. . American Journal of Community Psychology, 34(1/2), 1-69.

Úcar, X. (2012). Social pedagogy in Latin America and Europe: looking for new answers to old questions. In J. Kornbeck and N. R. Jensen (Eds.), Social pedagogy for the entire lifespan, Volume 2. Bremen: EuropauscherHochschulverlagGambH\& Co. KG.

Úcar, X. (2013). Exploring different perspectives of social pedagogy: towards a complex and integrated approach. Education Policy Analysis Archives, 27(36), 1-19.

\section{Notas / Notes}

${ }^{1}$ Algunos, por ejemplo Patton (2008) argumentarían que una tercera función de "generación de conocimiento" es fundamental para la evaluación. Sin embargo, replicaríamos que esta función difumina los límites entre evaluación, que consideramos que necesariamente implica un juicio de valor, y la investigación en ciencias sociales que puede no implicar este juicio.

2 Some, e.g., Patton (2008) would argue that a third function 'knowledge generation' is fundamental to evaluation but we would counter that this function blurs the lines between evaluation, which we see as necessarily implicating judgement, and social sciences research which may or may not implicate judgement. 


\section{CÓMO CITAR ESTE ARTÍCULO / HOW TO CITE THE ARTICLE}

Chouinard, J. A., Milley, P. \& Cousins, J. B. (2014). Intersecciones entre evaluación participativa y pedagogía social. Pedagogía Social. Revista Interuniversitaria, 24 137-162. DOI: 10.7179/PSRI_2014.24.06

Chouinard, J. A., Milley, P. \& Cousins, J. B. (2014). Intersections between participatory evaluation and social pedagogy. Pedagogía Social. Revista Interuniversitaria, 24 137-162. DOI:10.7179/PSRI_2014.24.06

Fecha de recepción del artículo / received date: 16.1.2014

Fecha de revisión del artículo / reviewed date: 20.1.2014

Fecha de aceptación final / accepted date: 28.IV.2014

\section{DIRECCIÓN DE LOS AUTORES/ AUTHOR'S ADDRESS}

J. A. Chouinard. 72 Harmer Ave, Ottawa, ON, Canadá, KıY oT8. Dirección de correo /e-mail: chouinardjill@gmail.com

\section{PERFIL ACADÉMICO / ACADEMIC PROFILE}

Jill Anne Chouinard, Ph.D. is an evaluation and social change consultant affiliated with the Centre for Research on Education and Community Services (CRECS), University of Ottawa. Her main interests in evaluation are in cross-cultural approaches and the use of participatory evaluation processes as leverage for social change. She received her Ph.D. in organizational studies and evaluation in 2010 from the University of Ottawa and has recently accepted a position at the university of North Carolina at Greensboro.

Dr. Peter Milley. Assistant Professor in the Faculty of Education at the University of Ottawa. He completed his PhD in educational administration in 2005 at the University of Victoria and has written on the moral, political, emotional and aesthetic dimensions of educational leadership, drawing inspiration from the Critical Theory tradition. Dr. Milley also has significant practical experience in leadership development, policy research, and workplace learning from a successful career in the Government of Canada. He has researched, presented, and taught in numerous countries, notably Brazil, China, the Netherlands, Singapore and the United Kingdom.

J. Bradley Cousins. Professor of Evaluation at the Faculty of Education, University of Ottawa. Cousins' main interests in program evaluation include participatory and collaborative approaches, use, and capacity building. He received his Ph.D. in educational measurement and evaluation from the University of Toronto in 1988. Throughout his career he has received several awards for his work in evaluation including the 'Contribution to Evaluation in Canada' award (CES, 1999), the Paul F. Lazarsfeld award for theory in evaluation (AEA, 2008) and the AERA Research on Evaluation 'Distinguished Scholar Award' (2011). He has published many articles and books on evaluation and was Editor of the Canadian Journal of Program Evaluation from 2002 to 2010. 